Modernity, plastic spectacle, and an imperfect utopia: A critical reflection on "Plastic Paradise" (1997) by Choi Jeonghwa

Park, Soyang

Suggested citation:

Park, Soyang (2018) Modernity, plastic spectacle, and an imperfect utopia: A critical reflection on "Plastic Paradise" (1997) by Choi Jeonghwa. Cross-Currents: East Asian History and Culture Review (27). pp. 51-78. Available at http://openresearch.ocadu.ca/id/eprint/574/

Open Research is a publicly accessible, curated repository for the preservation and dissemination of scholarly and creative output of the OCAD University community. Material in Open Research is open access and made available via the consent of the author and/or rights holder on a non-exclusive basis.

The OCAD University Library is committed to accessibility as outlined in the Ontario Human Rights Code and the Accessibility for Ontarians with Disabilities Act (AODA) and is working to improve accessibility of the Open Research Repository collection. If you require an accessible version of a repository item contact us at repository@ocadu.ca. 


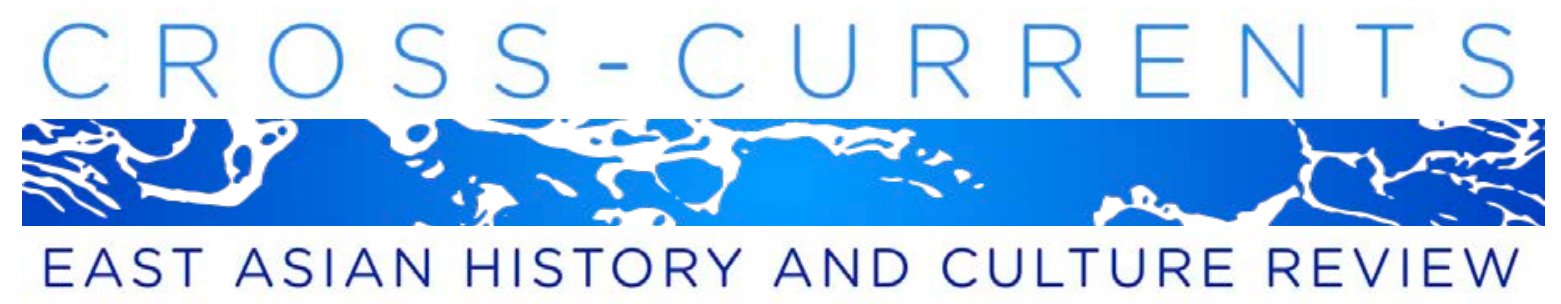

\title{
Modernity, Plastic Spectacle, and an Imperfect Utopia: A Critical Reflection on Plastic Paradise (1997) by Choi Jeonghwa
}

Soyang Park, Ontario College of Art and Design University

\begin{abstract}
Plastic Paradise (1997), a massive yet precarious-looking vertical installation made of cheap, mass-produced industrial consumer goods found in popular places in Seoul, is one of a series of installations that South Korean artist Choi Jeonghwa (b. 1961) has produced since the mid-1990s. With architectonic metaphors that enact a uniquely self-reflective critique of Korean modern society and its ethos, this excessively vertical installation signifies the utopian hope of the Korean masses toward industrialization. However, its fragile material structure alludes to a counterutopian reality latent in Korea's compressed growth (apch'uksŏngjang). This article provides a reading of the visual and tactile elements of Choi's art, which presents its unique structure as a cue for a nuanced social critique. Presenting samples of mass production as testaments to a modern utopia, Plastic Paradise critiques the pervasive myth within a society of mass consumption that these goods have become the totem of happiness "for all." Inspired by Choi's original observation of the dynamic form of the life of the masses, the installation also demonstrates how their seemingly mundane, everyday life is punctuated by the iconoclastic utopianism that they embrace for the future, and their understated creativity that continues to adapt and transform the given environment. In this way, the installation becomes both a monument and an antimonument to the state of development and its pervasive optimism.
\end{abstract}

Keywords: South Korea, modernity, compressed development, Choi Jeonghwa, utopianism, dystopia, kitsch, plastic, readymade, street market, pop art, minjung art, democratization, mass consumption, mass production, imperfect utopia, popular creativity, city, spectacle, Miracle on the Han River, contemporary art 

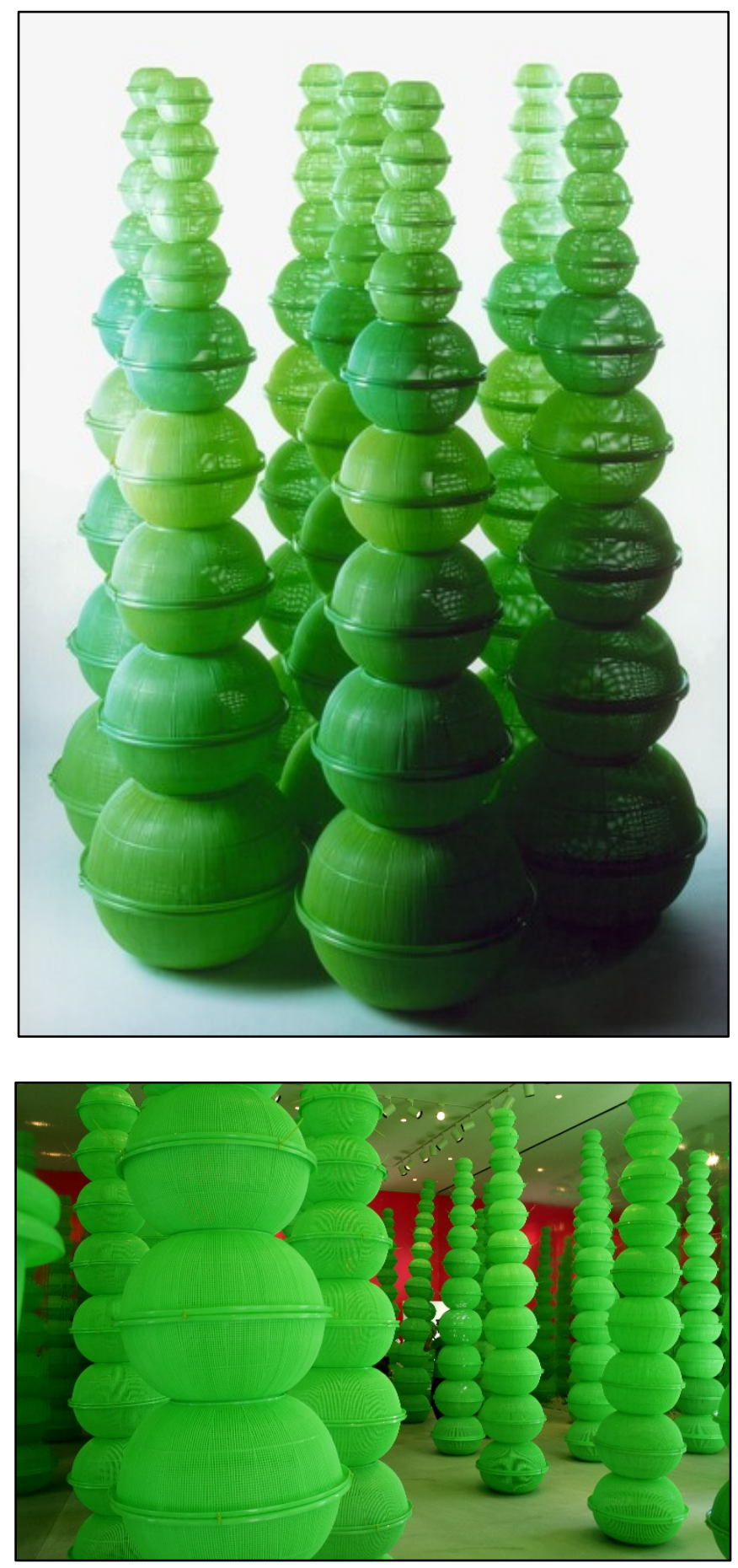

Figures 1a (top) and 1b (bottom). Plastic Paradise (1997) by Choi Jeonghwa. All images of Choi's work are used with permission of the artist. 


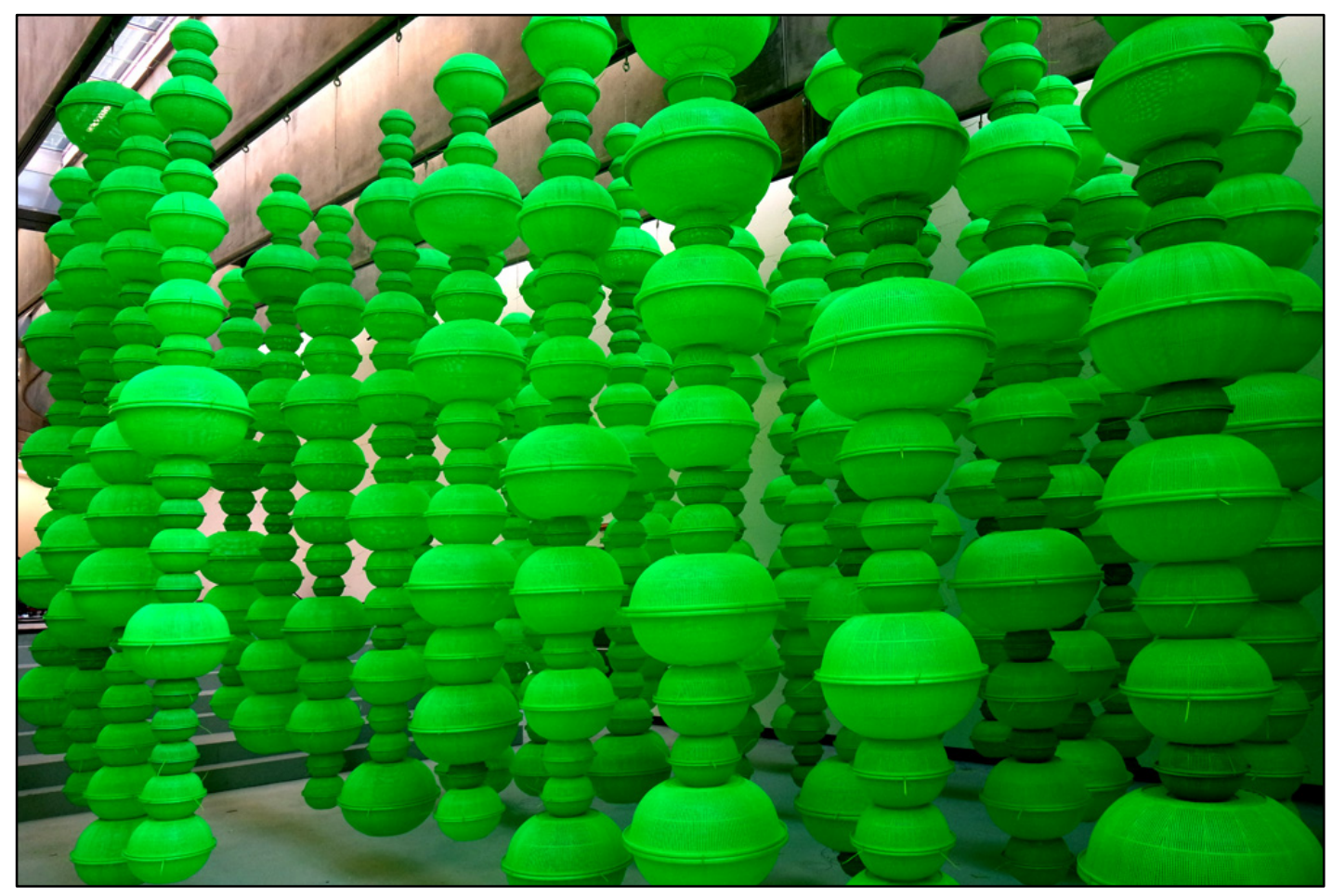

Figure 1c. Transformer (2015) by Choi Jeonghwa. National Museum of XXI Century Arts. Roma.

\section{Plastic Spectacle and a Dream of Utopia}

The words brought to my mind by Korean cities are crowdedness, extreme freshness, fusion, mix-stew, makeshift, colorfulness, fake, flimflam fabrication.... These characteristics are not really negative elements for an artist. I want to make them into a new aesthetic language. Crowdedness as a new aesthetic language; freshness as an "aesthetics of rawness"; fusion, mix and colorfulness as a "contemporary folk aesthetic"; fake and pusil [flimflam fabrication] as an aesthetics of "intense carelessness" as opposed to the aesthetic notion associated with that of refinement. I believe one can extract a new sense of beauty from these.

- Choi Jeonghwa (1999, 147, emphasis added $)^{1}$

There, my art is over there too.

- Choi Jeonghwa (Ahn 1996b, 29-30)

Plastic Paradise (1997) is a massive yet precarious-looking vertical installation made of cheap, colorful, and ubiquitous plastic colanders (figure 1a). This is one of a series of installations that the South Korean artist and designer Choi Jeonghwa has produced since the mid-1990s, inspired by mass-produced industrial consumer goods collected from popular places - traditional markets 
(chaelaesichang), urban street corners, and residential alleyways - in Seoul, South Korea, the city in which he grew up. Made of a large quantity of low-end green round plastic colanders in various sizes, stacked higher than eight feet, ${ }^{2}$ this installation with its impressive verticality and scale evokes the image of skyscrapers in a modern city. Yet the ephemerality of thin, hollow plastic colanders sustaining this towering structure does not allow viewers to retain such an illusion for long. The visual and tactile elements of this installation - shallow and ephemerally kitschy, yet unabashedly optimistic and ambitiously spectacularized - are in mutual tension, a factor that evokes a certain critical reflection on the phenomenon this work is assumed to transubstantiate.

Choi's work, which emerged in post-1993 Korean ${ }^{3}$ society as decades of military authoritarianism finally drew to an end and a new cultural milieu was arising, ${ }^{4}$ hailed a new artistic expression that is perceived to have signaled a postmodern and post-avant-garde turn in the Korean art world. ${ }^{5}$ In previous decades, the Korean art world was polarized by the reductionist abstraction of the Monochrome school (an indigenous abstraction art movement), which dominated the art world throughout the 1970s, and the often-didactic political realism of minjung (people's) art, which challenged the Monochrome school since the late 1970s in tandem with the popular democratization movement sweeping the country. Filled with lighthearted wit blurring the boundaries between high art and popular culture, and actively incorporating the readymade ${ }^{6}$ to challenge the notion of originality in art, Choi's art clearly set a new tone against the purist, didactic sentiment that dominated the previous decade's Korean art world. The majority of Korean art critics have captured the gist of his expressions through terms such as "kitsch," "shock," "the periphery of industrial society," "postauthoritarian," "unorthodox," "rebellious," "new generation," and "vernacular realism," with an interesting distinction in the initial responses from academic critics and nonacademic critics, ranging from surprise with a sense of unease to a welcoming gesture. ${ }^{7} \mathrm{~A}$ further in-depth art-historical assessment of his work beyond what has been conveyed through a plethora of short art-critical, journalistic, and curatorial essays published in Korean and sometimes in English seems imperative. ${ }^{8}$ This article, however, focuses on a differential reading of the visual and tactile elements of Choi's art, which presents its uniquely architectonic structure as a cue for a nuanced social critique. In a nutshell, this characteristic, seen not only in Plastic Paradise but throughout Choi's installations, interacts with the revisionary critical vision that arose in post-1993 Korean society characterized by its double-edged viewaffirmative yet critical — on the state of its modernity and its ethos. 
Born in 1961, Choi belongs to the generation that grew up in rapidly growing cities during the period of accelerated industrialization and growth in South Korea. The country that had been largely an agriculture-based economy in the early 1960s became a leading industrial nation by the late 1970s, a feat known as the "Miracle of Han River." "This "miracle" involved leaping forward from being one of the poorest countries in the world right after the Korean War (1950-1953) to becoming an economic powerhouse within a few decades. ${ }^{10}$ The particular experience of the cities during this period of rapid growth seems to have made a profound mark on Choi in shaping his aesthetic, creative, and social vision. He witnessed how Seoul, in particular, became filled with fresh, raw energy from the influx of people from all around the country (Choi 1999). More specifically, Choi was fascinated by the fact that the seemingly mundane everyday life of the people, represented by the mass-produced goods they used daily, was punctuated by an aura of optimism about the future and by their understated creativity in continuing to adapt and transform the given environment.

Plastic Paradise is thus construed as a carefully contrived cue for narrating the many layers of stories of Korean modernization and the masses whose lives evolve around these objects. For example, one of the key stories this installation attempts to narrate is the exciting optimism that has dominated the city and Korean society as a whole during the period of accelerated growth. This aura of optimism is indeed a characteristic surrounding all of Choi's installations, underpinned by their vibrant kitsch aesthetic. It is also an effect of the nomenclature Choi uses. The titles of these installations contain narratives of utopian optimism: P'üllasŭt'in P'aradaisŭ 플라스틱 파라다이스 [Plastic paradise]; Saek, saek, saek 색, 색, 색 [Color, color, color] (1994, figure 2); So Far So Good (1995, figure 3); Plastic Happiness (1995, figure 4); Kapkap'ame taehayŏ-Ŏnŭ robot'ǔŭi chukŭm 갑갑함에 대하여 - 어느 로보트의 죽음 [About being irritated-The death of a robot] (1995, figure 5), ${ }^{11}$ and Plastic Paradise, Encore, Encore, Encore (1997, figure 6), among others. Cheap light bulbs, colorful synthetic pig heads, silk flowers, a plastic piggy bank, plastic balloons, plastic toy robots, and synthetic golden trophies are samples of the popular consumer culture ubiquitous in the city, and they are presented (on their own, as well as together) as a means of narrating the story of industrialization, growth, and the utopian hope of the masses. 


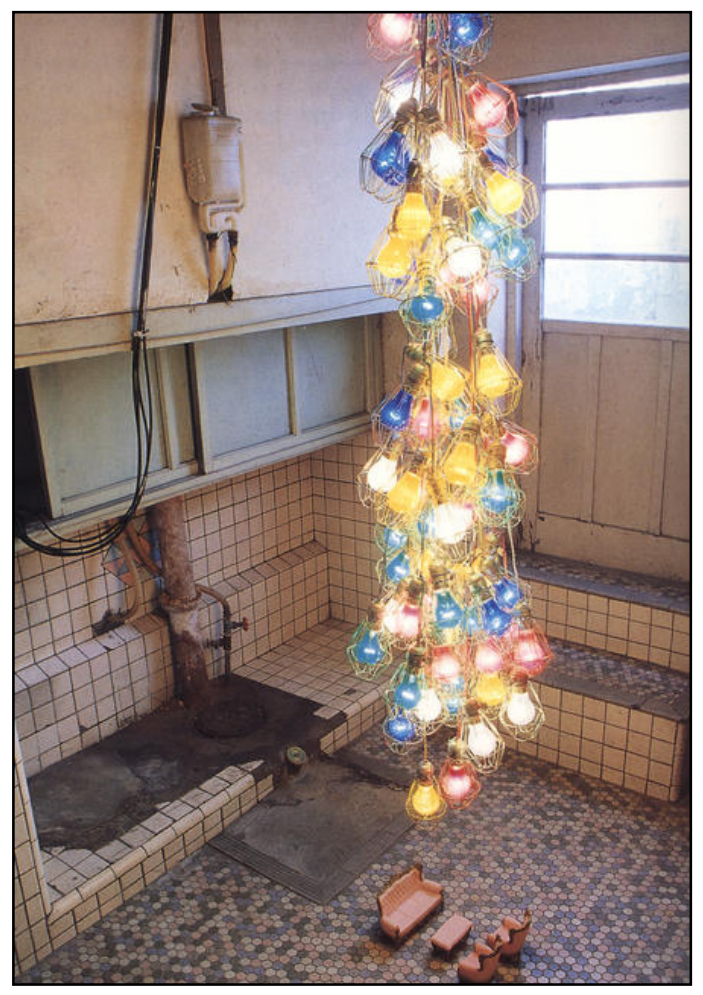

Figure 2. Color, Color, Color (1994) by Choi Jeonghwa.
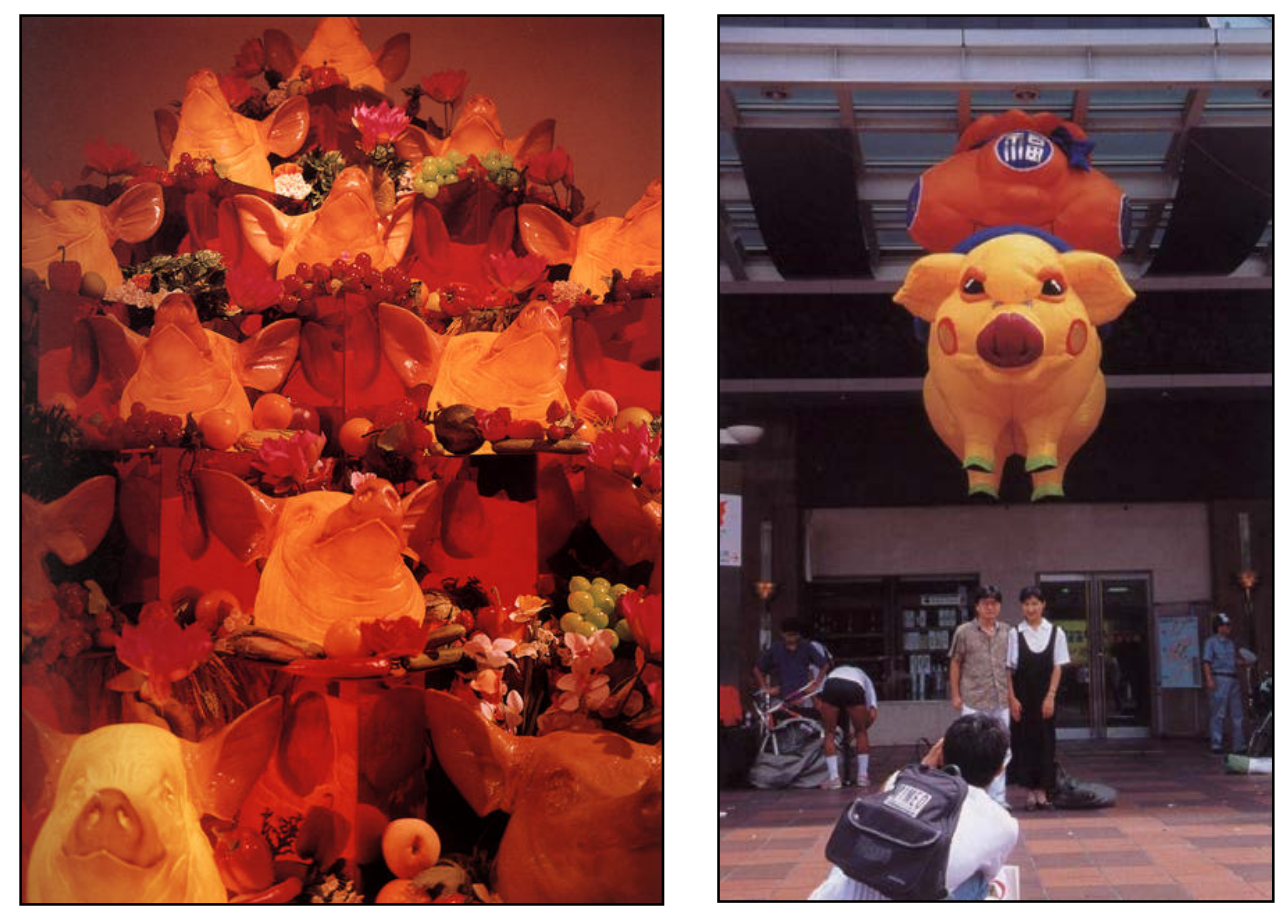

Figure 3 (left). So Far So Good (1995) by Choi Jeonghwa. Figure 4 (right). Plastic Happiness (1995) by Choi Jeonghwa. 


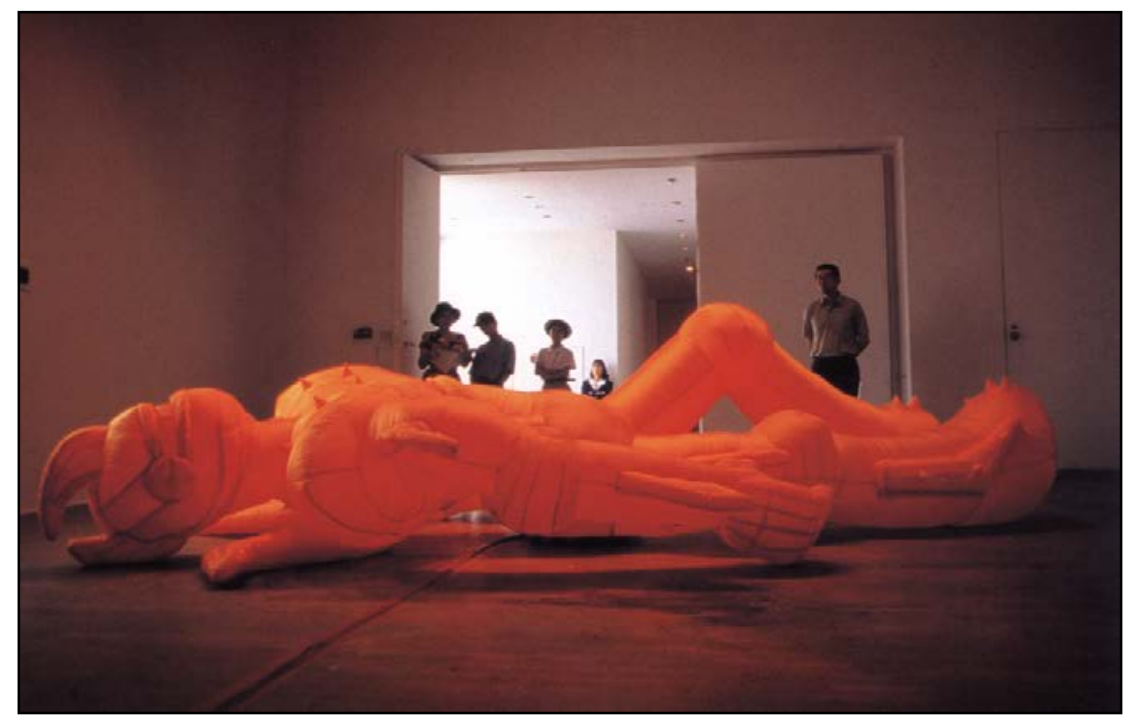

Figure 5. About Being Irritated - The Death of a Robot (1995) by Choi Jeonghwa.

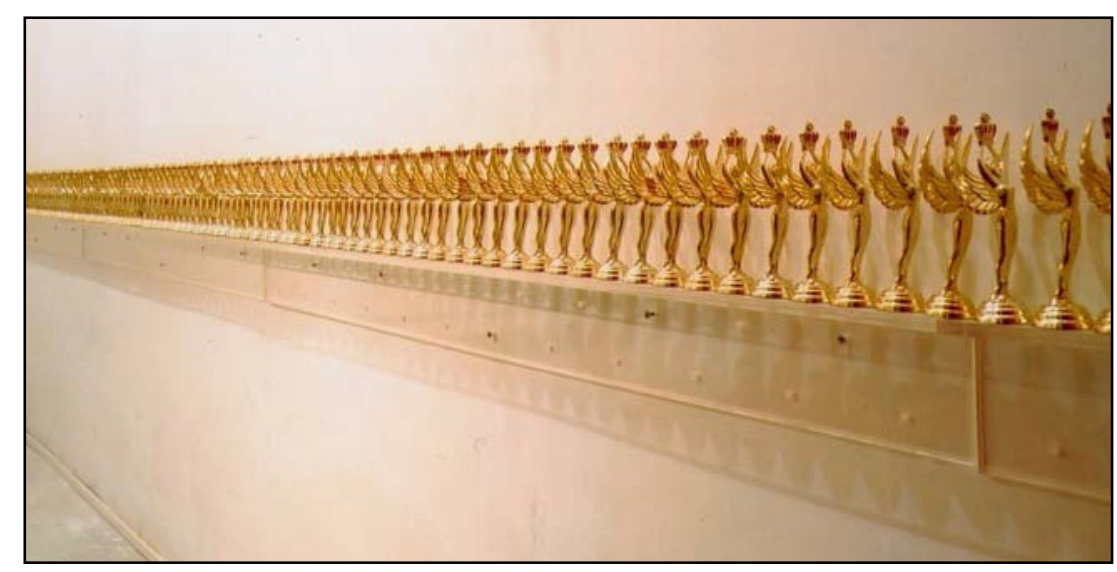

Figure 6. Plastic Paradise, Encore, Encore, Encore (1997) by Choi Jeonghwa.

Another way Choi's installations narrate the story of the masses' optimism in a manner pertinent to the era of accelerated growth is through monumentalizing the utopian values innate in industrial mass-produced goods. Choi samples and assembles the consumer goods in a way that accentuates their abundance, versatility, and expendability as a condition of the utopia that industrialization has enabled through its capacity for infinite production and replication of these objects. It is also possible that the sampled goods are narrating, more specifically, how mass consumption has become a way of life in post-World War II industrial liberal society across the globe; the consumer goods have become the primary means by which this society achieves its social goal of egalitarianism (Cohen 2003; Rupert 1995, 160; Williams 1982). Put another way, 
the infinite cycle of production and consumption of ever new products has become the means to "bring happiness and personal fulfilment" (Dunn 2008, 8) for citizens who have then transformed themselves into "constantly moving happiness machines" (Curtis 2002). Plastic Paradise may, then, be narrating how that global phenomenon made its way into this region, conveyed through the nuanced visual narratives of its particular and syncretic mode of localization. From this perspective, the ephemerality of versatile low-end consumer goods, which contributes to the tactile characteristics of this installation, also seems to trigger the story of a utopian aesthetic in the age of mass production. Distinguished from permanence and uniqueness (McHale 1969, 101, 103), the traits that cultural objects of the preindustrial era stand for, ephemerality is the key condition of the "mass-replicability" and "expendability" of these objects available at the disposal of the masses. In an essay titled "The Plastic Parthenon," British artist and sociologist John McHale echoed this idea as the utopian aesthetic of "a materially ephemeral present and future" (1969, 103). ${ }^{12}$

\section{Ephemerality: The Symptom of Compressed Development and the Memory of Counter-}

\section{Utopia}

The aura of optimism surrounding Plastic Paradise witnesses the utopian impulse within the society that enabled the Miracle of Han River. The work offers an affirmative recognition of the masses' optimism toward industrialization and of the egalitarian dream innate in industrial society through mass consumption. Yet the ephemerality of this towering structure of amassed kitschy consumer objects - the appearance of which is somewhat laughable-stops us from reading the installation as just an innocent celebration of such optimism and simultaneously prompts a critique of it. The uneasy hollowness of this spectacular monument of low-end consumer goods signifies an empty spectacle that embodies traces of memories of the failure of the utopian dream, or optimism, and of the counter-utopian reality within the state that has undergone what is commonly dubbed "compressed development" (apch'uksöngjang). This concept addresses the accelerated mode of development that "late developers" in East Asia (the "Four Dragons," including South Korea, Singapore, Taiwan, and Hong Kong) have undergone over a much shorter period of time than the "early developers" in Europe and North America have taken for their development. ${ }^{13}$ According to D. Hugh Whittaker and others, these East Asian "late developers" share and expose similar vulnerability to various internal and external challenges. For example, 
the "policy stretch" they have been commonly involved in as a measure of the "adaptive state" made them become especially vulnerable to "corruption" and "external disruption" (Whittaker et al. 2008, 18). In a nutshell, as a contrived empty plastic spectacle, Plastic Paradise can be read as a satire of the vulnerability innate in the state, which was once celebrated as a model for other developing countries in the world but has become the object of close scrutiny.

It is against this backdrop of accelerated growth bearing a tremendous vulnerability that Plastic Paradise, which seems at first to be a monument to optimism, calls to mind the contradicting imagery of recent historical disasters. These include memories of traumatic events such as the collapses of the Sorngsu Bridge and the Samp'ung department store in the middle of Seoul in the mid-1990s (figures 7a and 7b). ${ }^{14}$ These two consecutive collapses (the former killing thirty-two commuters and wounding seventeen in October 1994, and the latter killing 506 shoppers and wounding 940 only eight months later, in June 1995) plunged Korean society into profound shock, especially since these public structures were themselves symbols of the "miracle," Korea's accelerated growth and proud modernization. The bridge was built in the 1970s during the apex of rapid industrialization under the military regime as a key part of the infrastructure of the country's development; the lavish Samp'ung store, constructed 1987-1990, was a shrine to luxury goods for the newly rich residing in the Gangnam district. The collapses thus sounded an alarm for Korean intellectuals and served as a catalyst for reassessing the much-celebrated development model, the state of its development, and its sustainability with a renewed critical consciousness.

It is indeed telling that Plastic Paradise and other installations by Choi that embody this paradox - optimism on the one hand and vulnerability on the other-were being produced during the mid-1990s - the same years as these traumatic events. ${ }^{15}$ Questioning the sustainability of the country's modernity and its development model, the ephemerality of the installations conveyed by their hollowness and seeming fragility recalls the vulnerability within the infrastructure of the society, thus foregrounding the condition that cannot preclude such disasters. The culprit of these collapses, as the ensuing investigation revealed, was indeed the corruption endemic in the political, business, and private sectors of the country, which Whittaker et al. (2008) have acutely pointed out. In particular, Korean bureaucrats and business owners routinely justified short- circuiting as 

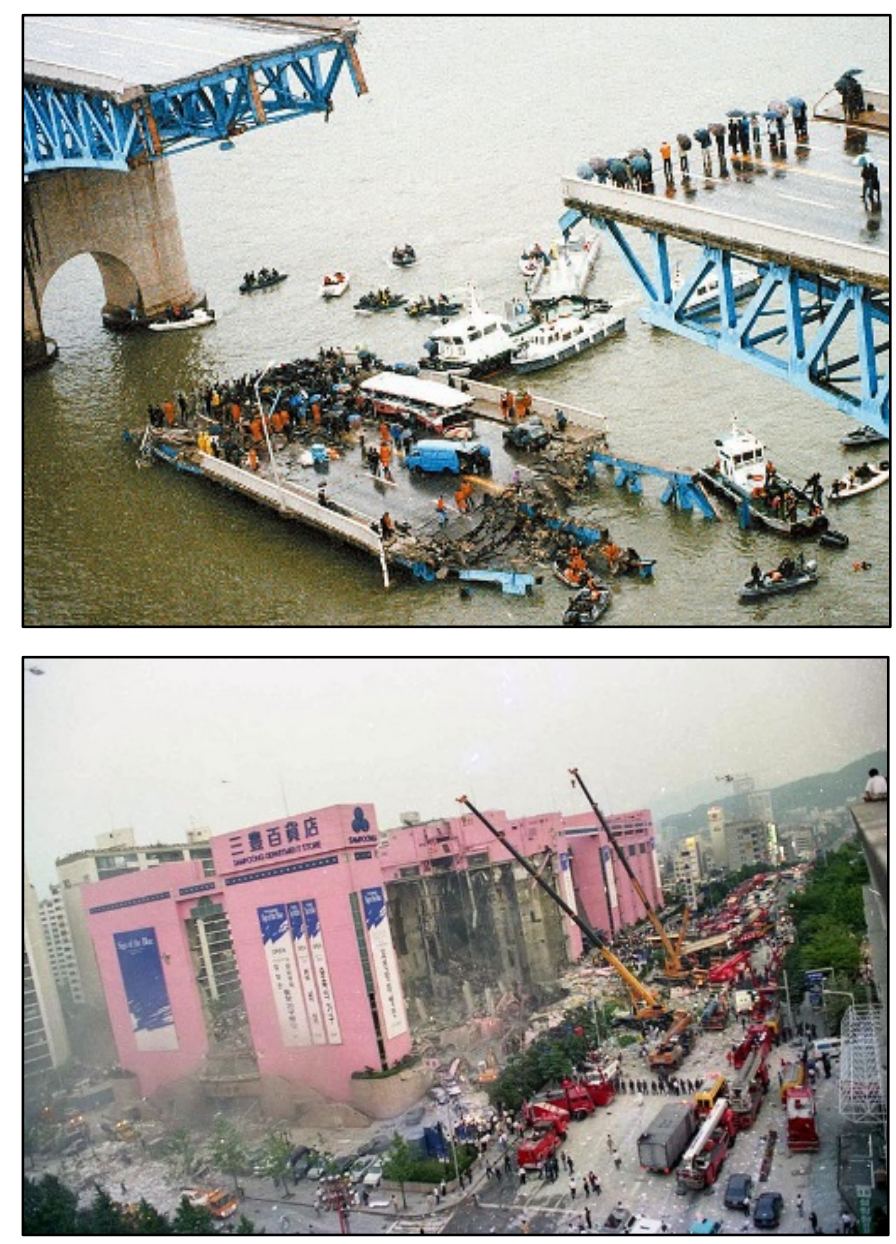

Figures 7a (top). Collapse of the Sŏngsu Bridge (1994). Source: Yonhap News Agency. Figure $7 b$ (bottom). Collapse of the Samp'ung store (1995). Source: Yonhap News Agency.

being "inevitable" for a late-developing country, which provided fertile ground for corruption and other forms of misconduct. Korean developers of large-scale public building projects since the 1970s were also regularly involved in illegally shifting to inferior building materials after safety certifications had been issued. Bribing corrupt bureaucrats, who in return turned a blind eye to this practice and to the routine negligence of safety maintenance, was also commonplace among these developers. ${ }^{16}$

The tension between the spectacularized tower of mass-produced industrial goods and the shallowness of the materials supporting the tower itself seems to echo the condition of intellectual consciousness of the era by probing into the paradox and the malaise within a society that has undergone such a compressed mode of development. Especially after the collapses of the public 
structures turned the story of "the Miracle of Han River" into "Disasters on the Han River," the discourse of "compressed development" has provided an appropriate tool for Korean intellectuals seeking a renewed critical paradigm to diagnose their status quo. Domestically, the publication of Kim Jin-Kyung's How Can One Who Lived Three Hundred Years in Thirty Years Be Oneself? (1996) acted as a catalyst for this major critical shift. This book came out within a year after the collapses and highlighted the unsustainability of the country's relentless development, preoccupied as it was with growth alone and overlooking so many other important issues. The flexibility (yungt'ongsŏng) and speed (sokdo) in which Koreans had taken so much pride were now perceived as the culprits behind actual and imminent disasters.

The double-edged vision - affirmative yet critical — that can be inferred from Choi's installations clearly echoes the revisionary critical ethos innate in this new paradigm of development, which greatly differs from the dominant critical discourse of the country's socioeconomic shift during the period of popular protest for democratization (dubbed the "minjung movement") in the previous decade. The 1980s minjung critics, who conducted long-delayed critical reflection on the country's modernization since the nineteenth century, focused on political and economic injustices perpetuated in the state's prioritization of growth and development over justice and democracy. They also paid close attention to the stigmatizing role of the international geopolitical (neocolonial) power in perpetuating this condition, with a keen interest in the politics of decolonization. The strong influence of the anticapitalist (anti-neocolonial) paradigm on minjung critics tended to employ a rigid binary vision of social forces. That vision emphasized the inherently oppressive and exploitative nature and structure of the developmental state formulated by the military regime. The paradigm critiqued the state for exacerbating the disparity of wealth in the society and perpetuating poverty among the underprivileged masses and laborers. However, the reborn civil society, which developed after the victory of the democratic movement in the 1992 presidential election, felt a need to revise this critical paradigm. The victory endowed the society with new hope and optimism, making the rigid anticapitalist paradigm seem too ideological and limiting, precluding other viable critiques of the development model and the status quo. The "compressed development" discourse served the need for a new critical discourse within Korean intellectual society well and thus became widely popular. After Kim's book, many publications documented the ills and the paradoxes within Korean development and its status quo, using 
"compressed development" as their critical framework and referencing the recent collapses as evidence of those ills, paradoxes, and drawbacks (Hong et al. 2006, 36-40; Lee SY 2014).

The manner in which Plastic Paradise presents the paradox that came about through compressed development effectively insinuates how the Korean masses' dream of modern utopia and happiness might be endearing yet untenable. That is, Choi's double-edged vision, as inferred from the tension between the visual and tactile elements of the installation, does not just celebrate or negate the present; unlike the once-dominant anticapitalist paradigm, it overcomes the negation of the present. Choi's critical strategy engaging with the paradox within the normalized present does not profess a direct or explicit critique of the society but enacts a critical vision by conjuring up another suppressed memory of the counter-utopia within the state of celebrated growth. The hollow body of the tower of abundant consumer goods indeed evokes a dialectical image, a void at the center of the spectacle. From this void, the work triggers traces of the memory of counterutopian reality that the developmentalist state attempted to elide through its ideology, or myth, of "(national economic) growth" and the expanding consumer spectacle. The myth of national economic growth (seongjang sinhwa) that the authoritarian state instilled in the masses-which seems to have continued to inform the social psychology of Koreans even after the 1990s - is defined by prioritization of the (national economic) growth as a conduit for a universal solution, toward "happiness for all." The famous imperative of the Park Chung-Hee era urged "individual sacrifice until the national goal is achieved," promising that such sacrifice would eventually guarantee fair share and happiness for all. Park (1917-1979; South Korean president from 1961 to 1979) is famous for designating this myth and perception, which helped him effectively implement his famous economic blueprint, Five-Year Economic Development Plan (Kyŏngje 5kaenyŏn Kaebal Gyehoek), in 1962. Combined with a nationalist conviction that national economic growth would redeem the nation and its people from the historical plights and poverty left by Japanese colonialism (1910-1945) and the Korean War, Park's imperative was convincing, and it successively moved the public to wholeheartedly embrace his plan.

Throughout Park's nearly two-decade reign, the Korean masses subjected themselves to the demands of relentless mobilization through flexible adaptation, which enabled unprecedented accelerated growth, at the cost of the world's longest working hours and lowest wages. ${ }^{17}$ The authoritarian regime and social elite promoted Park as the national hero, crediting his development plan and leadership as the foremost source of the nation's "economic miracle." As a deeply 
ideological state practice, however, this rhetoric was also simultaneously used to justify the regime's brutal suppression of burgeoning public demands for fair distribution of economic growth and further democracy. ${ }^{18}$ The regime's popular imperative-"momentary sacrifice of the individual (citizens)"-soon became a point of contention. The self-immolating protest of the young textile worker Chŏn T'aeil (1948-1970) on November 13, 1970 attested to the growing discontent among workers who then formed the majority of the population. ${ }^{19}$ The subsequent popular democratization movement of the 1980s, wherein a grand oppositional coalition of antagonized students, intellectuals, workers, peasants, and members of the middle class was formed to counter the political and economic injustice normalized under the authoritarian regime, attests to the public's general disillusionment with the myth of growth Park had constructed and perpetuated.

\section{The Myth of Consumer Society and Popular Creativity}

In addition to triggering a critical reflection on the constructed myth of (national economic) growth that continues to haunt Korean society after the era of authoritarianism, Plastic Paradise prompts viewers to reconsider the pervading myth normalized in consumer society in which these consumer objects individually and together become its utopian testaments. Korea became a consumer society in the late 1980s (Robinson 2007, 7) wherein social phenomena and ethos of measuring one's self-fulfillment and happiness in terms of commodities and consumption became part of the public's way of life. Artists witnessing this shift throughout the 1980s certainly provided their critical responses. In particular, minjung artists paid particularly close attention to the ideological aspect of consumer culture and its alienating effects. The widening disparity of wealth and persistent economic injustice continued to exacerbate the sense of alienation among the underprivileged masses, while the expanding spectacle of consumer goods continued to project the illusion of "happiness for all."

The painting Lucky Monorium Guarantees a Prosperous Life (1981) by Kim Jeong-Heon (b. 1946) is an example of artwork that elucidates such a sense of alienation and engages in a critique of consumer society. Kim is one of the advocates of minjung art noted earlier, whose mission was to represent the underrepresented reality of the people and their voices in Korean society. This particular painting adopts the format of an advertisement in order to satirize the ideological aspects of a popular marketing slogan of 1980. It depicts a middle-class home furnished 


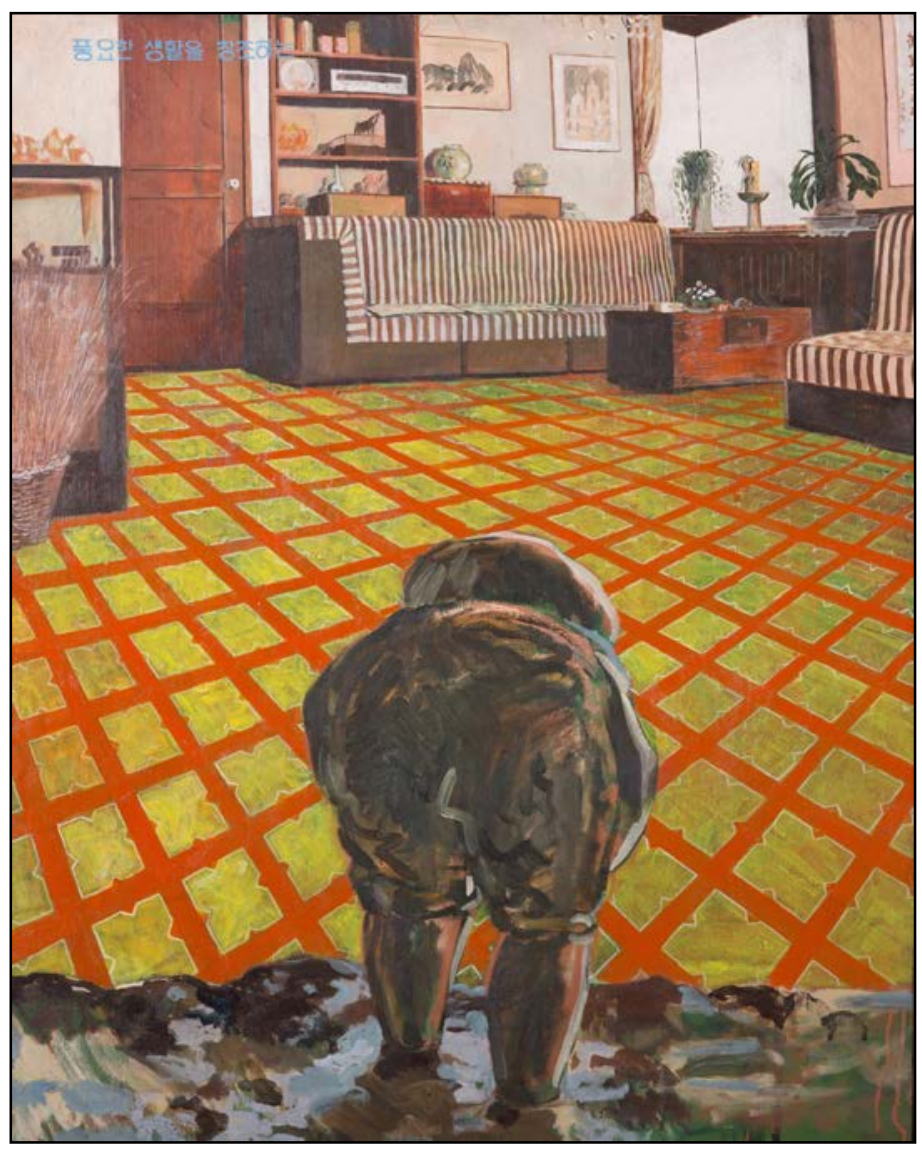

Figure 8. Lucky Monorium Guarantees Prosperous Life (1981) by Kim Jeong-Heon. Source: 2001 gift from Lee Ho-jae, GanaArt to the Seoul Museum of Art (SeMA). Used with permission.

with a fancy floor decoration brand called Lucky Monorium, the advertisement copy of which is found in the corner: "Lucky Monorium Guarantees a Prosperous Life." This scene of middle-class prosperity is directly in tension with the image of a poor farmer standing in a rice field in the foreground. Perspectival manipulation, achieved through resized patterning of the flooring, creates an optical illusion that amounts to creating a sense of alienation, suggesting what the farmer figure feels while looking at this middle-class home yet being perpetually distanced from it (figure 8).

While presenting a parallel critique of the myth of consumer society, Choi's installation series engages in the task quite differently. That is, his installations shift the critical ethos from one strongly based on a binary vision of social forces (as in Kim's Lucky Monorium) to one observing the interiority of this myth resulting from its internalization by the masses over decades of industrialization. This interiority addresses the state wherein ideology becomes an internalized desire, making the boundary between them more complex than binary. Precisely, Kim's Lucky 
Monorium renders social forces such as the state-the capitalist (the advertiser) and the workersfarmers (the farmer) in an oppositional relationship, typical of the vision of the 1980s prodemocracy, oppositional intellectuals, activists, and artists. It is important to note that as a university student in the mid-1980s, Choi was deeply sympathetic to the critical ethos of minjung artists, though with certain reservations and critical distance (Choi 2004). Minjung artists' mission to represent the lives of the underrepresented masses and the negation of the dominant aesthetic norms of the formalist abstraction greatly appealed to Choi. The serious and dark oppositional didactic tone of minjung art, however, did not, as Choi was becoming attuned to the more liberal and pluralist spirit of the coming era. As a next-generation artist emerging after the late 1980s and becoming active after liberalization in 1993, Choi has an ethos and gaze, inferred from his installations, that clearly reflects a certain optimism and pluralism, as well as the ambivalent, double-edged sentiment of the era. Namely, despite the positivistic and pluralist spirit beginning to permeate the postauthoritarian Korean society, the country's intellectual society still had to tackle the remnants of a relentless compressed development process. This ambivalent sentiment of the era undoubtedly informs the way Choi's art simultaneously presents a monument and antimonument to the status quo and the ethos of the masses in a consumer society.

As for pluralism, a postmodern discourse began to influence the Korean art world in the late 1980s, despite understandable local resistance to yet another cultural paradigm with universalizing implications extrapolated from the "assumed" center, the West. There is no doubt that this new discourse helped Choi justify his artistic direction beyond the polarizing aesthetic ideologies of the previous era and the universalist constraints of the Western aesthetic and art historical canon that burdened, haunted, and limited Korean artists. That is, the pluralist doctrine of postmodernism and its innate counter-universalist ethos must have helped Choi (and other artists of the new generation) to open up to new attitudes and artistic visions that allowed them to delve into the latent domains of embodied aesthetic (Park 2011, 107-108). Creating a symbiotic relationship with the liberalizing ethos of society, this new vision and attitude brought together a unique art collective known as "Museum" (1987-1990) with the motto, "Do as you like." "Museum" was founded by Choi, Lee Bul, ${ }^{20}$ and Ko Nak-Beom, all young graduates of Hongik University (Seoul), the country's prestigious art school, which was then dominated by the doctrine of the masters of abstract art. Their motto, "Do as you like," carried little in the way of art historical and aesthetic references, yet effectively directed these new-generation artists' liberal attitude and 
their attention to the language and issues within everyday culture as an embodied domain of the aesthetic potentially charged with social narratives. Under this motto, they (especially Choi and Lee) started actively adopting objects and motifs from everyday life and the surrounding environment as sources of inspiration and as newfound art materials. ${ }^{21}$ Their distinctively anti-art and anti-academic attitude - unlearning the taught norms and canons of art history — set them apart and enabled them to inspire a radical departure from the expressive limits that had hitherto stifled Korean artists (perhaps throughout the twentieth century) and from the prevalent aestheticism. The latter implicitly and explicitly had always necessitated a certain identification with aspects of the Western art historical and aesthetic canons and norms in order to seek validation of their expressive and aesthetic practices.

In relation to the surrounding environments, Plastic Paradise and most of Choi's installations produced since the 1990s were the outcome of his close observation of the everyday lives of the masses and the popular places he frequented in Seoul (traditional markets, urban street corners, residential alleyways, and so on), through which he gained a profoundly revisionary view of the nature of popular culture. Radically different from conventional representations-which have cast the culture of the masses in the modern industrial society as uniform, banal, and anonymous - Choi was instead inspired by the understated creativity of the anonymous people who shaped their environment through active use and adaptations. This "popular creativity," as I call it, is well manifested in the example of a small reformed plastic stool that Choi discovered on a street corner in Seoul (figure 9). This simple stool is part of Choi's collection of "found objects" from popular places and was originally a mundane mass-produced consumer object. Yet it has been reformed through attentive adaption by an unknown user who enhanced it with scraps of extruded polystyrene (otherwise known as Styrofoam) on the seating area for extra comfort and tightly duct-taped it for stability. This is just one example of such low-end, mass-produced objects adapted by their users for everyday purposes, and those familiar popular constructs found in the most unassuming places and corners in the city that reveal ingenious and creative designs of unknown men and women, which became a muse for Choi. Those adapted found objects ${ }^{22}$ and popular constructs discovered by Choi also include variously sized metal paint or oil containers simply modified and turned into fire pits in construction sites, or broken glass bottle fragments embedded in molded cement fences for added security. ${ }^{23}$ Each of Choi's installations takes inspiration from unpatented vernacular designs found in these objects and constructs. 


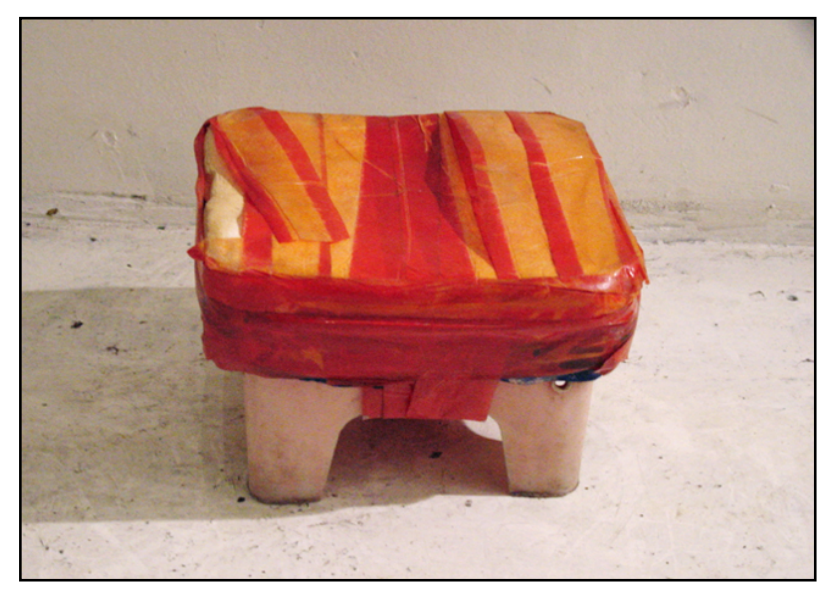

Figure 9. The reformed small plastic stool found on the streets of Seoul. Source: Choi Jeonghwa, personal collection.
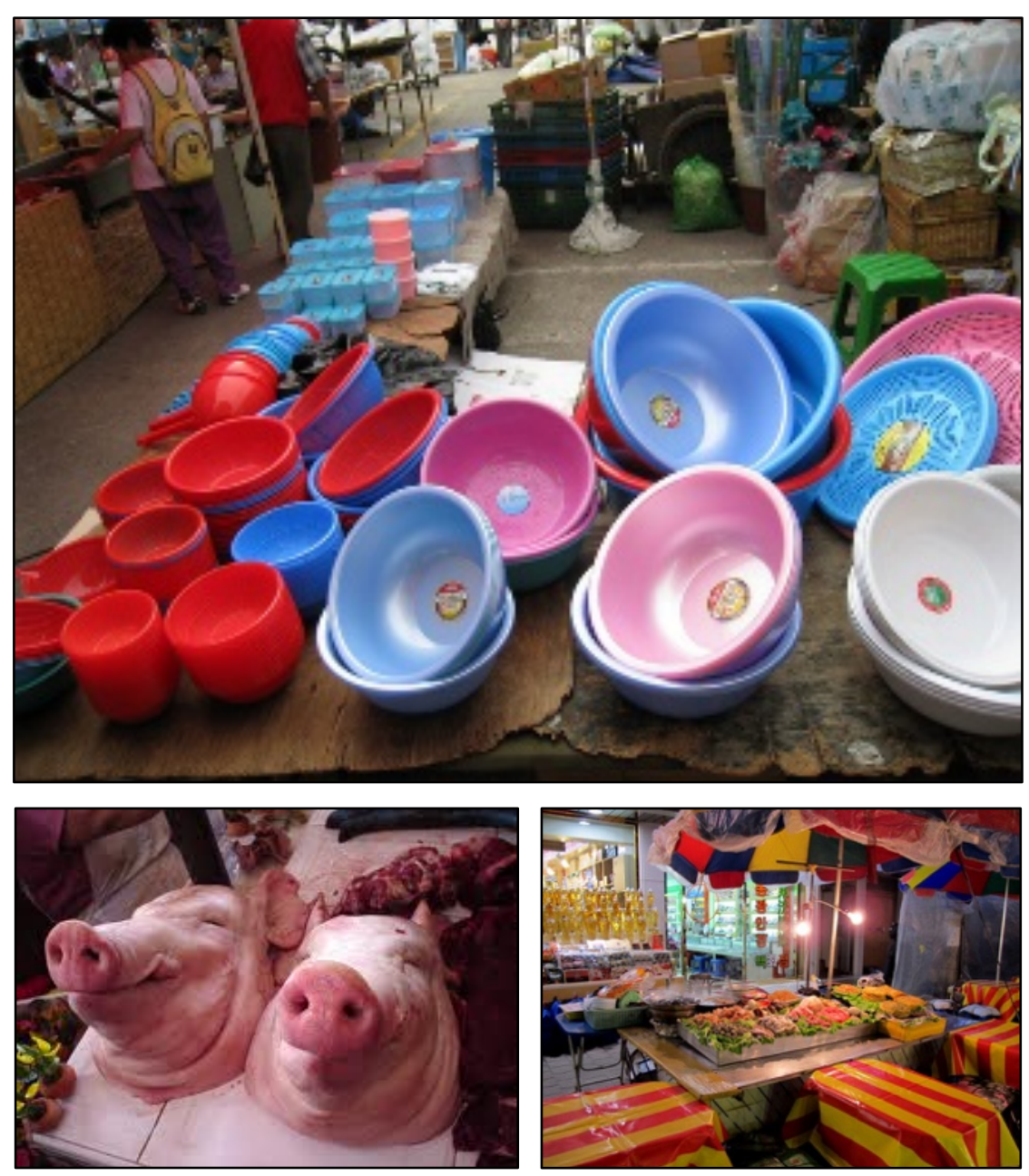

Figures 10a (top), 10b (bottom left), 10c (bottom right). The traditional market (chaelaesichang). Photos by Choi Jeonghwa (10a) and the author (10b and 10c). 
Plastic Paradise, in particular, seems to have taken its inspiration directly from the traditional market (figure 10a, 10b, 10c), one of Choi's favorite places to wander. The chaelaesichang traces its origin back to the open-air street markets in the premodern past. ${ }^{24}$ It has coexisted with modern industrialized stores inside buildings (often called mart in Korea) in an old yet rapidly developing city like Seoul, a highly "polarized and heterogeneous space" (Maderthaner 2008, 26-27). What is important to note in relation to Choi's aesthetic vision is that the traditional market has embodied the habitus of the urban masses from the lower economic strata, including the large number of migrants from the countryside, a common phenomenon in a place of accelerated development. Meanwhile, the mart typically attracts the more affluent urban populations or elites. For Choi, the traditional market thus becomes a site in which to explore the stories of class, economy, and culture, derive a true picture of the lives of the masses, and measure the modernity of the nation from the perspective of the masses. He not only has purchased a large quantity of plastic colanders for his installation at the market but also faithfully captures and replicates in the installation the dynamic optimism and energy coming from the diverse crowds that electrify the place. The active and resilient form of life he witnesses in the market are also shaped by the many layers of seemingly conflictual forces - the traditional and the modern, the commercial/transactional and the communal, the raw and the industrial - that continue to fuse and collide. As an indispensable part of the resilient life of the masses in the time of radical transition, these colorful plastic colanders are their everyday essentials. These products of modern industry replace what used to be made manually and in smaller quantities in local communities using natural materials like bamboo. Their vibrant industrial colors (red, green, blue, pink, and so on) -all adopted into Choi's color scheme - and diverse shapes (variously round and square) are thus interpreted as signifiers of the fantastic modern life that industrialization brought to the masses, capable of reproducing any household item in any color, shape, or quantity. Not only did Choi sample the colanders as specimens of the modern life of the masses and recapture the optimistic vibe they add to the already vibrant marketplace; he also seems to have taken from these market displays a hint for his simple and ingenious technique of tectonic construction of the installation. The way the sellers have stacked up plastic colanders of various shapes, sizes, and colors in front of their stores often looks like colorful monuments or pop sculptures. The famous statement Choi made while wandering through those popular places-"There, my art is over there too"elucidates his moment of encounter with an understated aesthetic order from the mundane 
environment, shaped by the (in)operative and (de)centralized multitude engaging in the making of everyday life. ${ }^{25}$ As if inspired by this, Choi simply stacked up more than a hundred of these plastic colanders through a simple and skillful adjoining technique: gluing two identical colanders together at the rims to make a globe and form a single module of the tower and repeating the same procedure with sets of colanders in different and serialized sizes. The installation emulating the mundane and vernacular aesthetic of the quotidian world of the streets - though adding his own twist to it - allows viewers to connect back to the people's stories of everyday life rather than displacing them from it. ${ }^{26}$ The seven towers of modular globes (Figure 1a) decreasing in size toward the top stand like majestic skyscrapers in a modern city, or even a minimalist sculpture, despite their ludicrous shallowness.

Choi's original dictum, "Everything is art, art is everywhere, and everyone is an artist" (Haengbogi-Gadŭk'an-Ghip 2006), nicely sums up his aesthetic vision inspired by the everyday culture of the masses. In concert with these ideas, he embarked on a radical departure from the conventional, elitist, and high-culture notions of art and creativity still dominant in the Korean art world in the 1990s, despite the adamant campaign launched by advocates of minjung art for more than a decade. His art indeed materializes a new democratic notion of art and creativity from its conception, the materials used, and the source of inspiration. To Choi, the "adapted" objects found in the everyday environment shaped by everyday people are not just sources of inspiration for his art. For him, they are already "works of art," though they have never been patented or credited to any particular individual. Domestically, Choi's attitude and vision echoes while revising the democratic notion of art that minjung artists initiated, based on new premises. Minjung artists attempted to realize the ideal of democratic art as art that represents the hitherto underrepresented people or masses, especially their sufferings, and the vision of their empowerment. As initiated by the democracy-seeking avant-garde artists, their visual productions in most cases (with some exceptions) amount to "art for people," rather than art "by people" or "of people." ${ }^{27}$ Underpinning Choi's revision is the belief that the multitudes are always already creative agents capable of active adaptation and recreation of the given environment. It is important to note that Choi's exhibition has also become a conduit for this vision by displaying and juxtaposing those (adapted) found objects and samples of popular construct side by side with works he has created himself, giving them equal importance (Choi 2014). ${ }^{28}$ His frequent, nuanced confessions and statements in interviews that his works "copy, steal, and plagiarize" (Wong 2003, 41) the discoveries from these 
popular places makes it all the more clear what the sources of his aesthetics are, away from the established canons of art history or the Parthenon of fine art collections.

\section{Conclusion: Plastic Paradise, an Imperfect Utopia and Iconoclastic Utopianism}

The abundant, shallow, kitsch plastic goods spectacularized through Plastic Paradise not only testify to the condition of the material culture of the masses in a "late developer" nation in the 1990s; they are also designated to narrate and reinforce the story of modern paradox - a penetrating theme throughout Choi's work-which is already innate in the industrial material, plastic. Choi's art seems to actively capitalize on the aspect of this found material, and his installations often positively narrate, on a surface level, the utopian hope associated with abundant plastic goods through the happy vibe surrounding them. Choi underscores this effort with the titles he assigns to his works by juxtaposing plastic with terms of optimism (Plastic Paradise, Plastic Happiness, and Plastic, Plastic, Plastic). Invented at the peak of industrial revolution, the qualities of plastic — its malleability and durability, as well as its being lightweight and low-cost-made material indispensable to the modern manufacturing industry. The mass-consumption society realized its utopian ideal of egalitarianism basically through this material whose versatility, affordability, and durability enable the infinite production of affordable consumer goods for all. However, the irony lies in the fact that such utopian qualities, especially durability, produced the dystopian condition from within modern society, which has been intoxicated by its own ability to produce those goods in infinity. The mounds of imperishable plastic goods strewn and lying in an industrial wasteland have thus become an iconic image of modern dystopia in the era of planned obsolescence. The perception of a paradoxical intersection of utopia and dystopia that Choi's plastic monuments evoke indeed implodes the innocent utopian optimism that it initially meant to narrate.

The spectacularized kitsch aesthetic of Plastic Paradise thrives in the contiguous perception of paradox innate in itself. The scene of the ephemeral kitsch unabashedly spectacularized - also found in So Far So Good (mass-produced identical synthetic pig heads that look more real than the real ones, stacked up like a tall religious altar) and in Plastic Paradise, Encore, Encore, Encore (sublime horizontal row of mass-produced identical fake golden trophy ornaments modeled on the Greek goddess of victory) - unmistakably evokes a profound void at the center of the phenomenon. Echoing observations by Austrian novelist Hermann Broch and 
literary scholar Eva Le Grande that kitsch is a self-deceiving "falsehood" 29 and "behind the mask of beauty, [it] conceals the conflictual reality" (Le Grand 1999, 12), this void indeed conjures up the imagery of many stories of dystopian and conflictual reality elided by the state. The state of miraculous growth for which this kitsch spectacle stands suppressed the voices of the underprivileged and hid away the story of human retrogression. The amalgamation of identity into a commodity relation that this spectacle of consumer goods symbolizes, being normalized in modern consumer society, has perpetuated, and will perpetuate, the alienation of everyone reified in the relation. Behind the facade seemingly celebrating the masses' optimism, the tower of abundant kitsch consumer objects may also insinuate a grim future for the masses, who have long sacrificed themselves in a happy dream for the future yet may be left forever stuck in the same circle of the low-end kitsch without ever reaching the outside of it. ${ }^{30}$

What makes Plastic Paradise such a paradoxical and complex monument to the state and stories of modernity and the ethos of people is the way it enacts narratives of conflation and conflict of differential or oppositional utopianisms in the developmental state, which shaped the condition of the present. American social critic Russell Jacoby provides apt metaphors in Picture Imperfect: Utopian Thought for an Anti-Utopian Age (2005). In this book, he asserts and discusses the inseparable relationship between utopia and dystopia and different forms of utopianism. One of the utopianisms that he discusses is "blueprint utopianism," the hitherto dominant utopianism that inevitably grows dystopia within as its "logical fulfilment" (Jacoby 2005, 7-8). That is, the blueprint utopianism strives for an idea of the future, driven by a single totalitarian image of a perfect society as mapped out by a small group of elites (Jacoby 2005, xv-xvi). Another utopianism noted by Jacoby is a less familiar yet "inevitable" one, which he dubs "iconoclastic utopianism." Iconoclastic utopianism addresses the exciting optimism that the multitude embraces while striving for an idea of the future that defies such a single totalizing image (2005, xvi). The latter is the utopianism that is conceivable as an alternative at the ruins of many failed modern utopias in the twentieth century (Jacoby 2005, 7). Plastic Paradise as a monument or antimonument, thrives in paradox and complexity due to its relationship to both utopianisms as an important part of the story of Korean development and its modernization. Indeed, the two utopian forces were conflated and conflicted throughout the period of the accelerated growth and democratization leading to the 1990s. That is, on the one hand, this installation may be read as a monument to Park Chung-Hee's blueprint utopianism, which dominated and instilled exciting 
optimism in the masses through his economic plan, leading to the accelerated growth. On the other hand, it may also be read as a monument to the iconoclastic utopianism embraced by the masses, who internalized Park's blueprint utopianism and devoted themselves to the project to enable the accelerated growth. In the process, they also engaged in an active interpretation of the original premises of the utopianism designated by the authoritarian elites. Iconoclastic utopianism seems to have brewed within this process through the decades of growth and mobilization, which led the masses to assess their reality against the illusion of utopia that the authoritarian elites tried to instill in them, in a contrived action that in fact deferred "happiness for all." Their protest throughout the 1980s proved the iconoclastic power of the masses striving for an idea of the future defying the top-down logic of "(individual) sacrifice." Choi's monument does not explicitly narrate the story of the masses' empowerment and protest but affirms it through the celebration of their resilience and transformative creativity, which his art actively emulates and monumentalizes.

In conclusion, the spectacularized tower of the abundant yet shallow plastic colanders Choi presents in Plastic Paradise perhaps insinuates how the result of compressed development driven by blueprint utopianism can collapse at any time. This tower simultaneously may also narrate how the multitude, who actually built it with their tremendous optimism, has been sustaining the structure with their resilience, iconoclastic adaptability, and creativity without letting it collapse. In this way, this installation may be read as a monument to an imperfect utopia against the backdrop of the ephemeral present and future, which continues to defy illusions of a singular picture of the present shaped by the economic miracle and punctuated by the collapses of public buildings.

Soyang Park is Assistant Professor in the Faculty of Liberal Arts and Sciences and School of Interdisciplinary Studies at Ontario College of Art and Design (OCAD) University.

\section{Notes}

1 This is a rare autobiographical essay by artist, designer (interior, architecture, graphics, and film art), and art director Choi Jeonghwa. Choi is famous for working across the boundaries between fine art, design, and the everyday with an intention to bridge these domains. His works transgressing the established norms of art led the Korean art world to nickname him an enfant terrible when he emerged on the scene in the 1990s. Choi detests the label of "artist" and frequently refers to himself as a designer (he opened a design and 
creative project office called Ghaseum Art Studio in 1992), or as a "Sunday artist," which also echoes his anti-art and anti-institutional stances (Wong 2003, 43). Choi garnered international fame after participating in several major international exhibitions, such as the second "Asia-Pacific Triennial of Contemporary Art" (1996) in Brisbane, Australia and "Contemporary Art in Asia: Tradition/Tension" (1997) at the Asia Society in New York.

2 Choi has created many versions of this installation in various sizes since 1997; some are larger in scale and taller than ten feet. See figures $1 \mathrm{~b}$ and $1 \mathrm{c}$.

3 In this article, "Korea" refers to South Korea (the Republic of Korea).

4 South Korean politics had been dominated by military authoritarian power since 1960. After more than ten years of popular protest for democratization throughout the 1980s, the 1992 presidential election finally ended military rule by electing Kim Young-Sam and brought about the much-anticipated liberalization of Korean society.

5 I will later explain Choi's relationship to the predominant abstract modernism and political realism of the previous decade. I use the term "post-avant-garde" here for a better transcultural understanding of the sentiment of new generation artists like Choi who gradually emerged starting in 1987. "Avant-garde" art here refers to minjung (people's) art, whose realist tenet was influenced by a strong belief in the revolutionary politics and the radical role of art. See Ahn (1996a, 69), Ahn (1996b, 29), HD Kim (1996, 45-47), J. B. Lee $(1996,65)$.

6 "Readymade" refers to manufactured and finished objects adapted by the Dada artists as "art objects" since the 1910s.

7 Critical writings published in Korean in the 1990s include Lee YW (1996) and Beck (1999). Those published after 2000 include Lee YJ (2004), Jeong (2008), and Park (2011, 107-108). I use the term "vernacular realism" in my 2011 article in relation to works of Oh Yoon (1946-1986) and Lim Ok-Sang (b. 1950), two representative minjung artists from the 1980s, and Choi Jeonghwa's works from the 1990s.

8 Academic papers with more critical depth have been published in Korean since 2011, years after my research for this essay was completed. I have presented the essential argument of this article in small Korean seminars since 2006 and at the Association of Art Historians (AAH) conference in the United Kingdom in 2011. Other academic papers in Korean include Shin (2011) and Yun (2013).

9 This term was inspired by the similar case of accelerated economic development in postwar Germany dubbed "the Miracle on the Rhine." The vast Han River runs through the center of the capital city of Seoul.

10 In 1962, Korea was as poor as Pakistan and the Congo. Rapid industrialization and economic growth laid the foundation for South Korea to become the ninth or tenth largest economic power in the world by the late 1990s (see Eckert et al. 1990, 388).

11 Among these works, About Being Irritated - The Death of a Robot is an anomaly, since Choi clearly attempted to narrate the failure of the optimism more explicitly in it than in his others through the motif of a deflating balloon robot.

12 John McHale (1922-1978) influenced the birth of U.K. pop art.

13 Major works on "compressed development" published by South Korean writers since 1996 include Kim JK (1996, 82-83), Bok (1998, 18), and Han (2003, 23-24). For literature contributed by scholars outside Korea taking account of compressed 
development, see, in addition to Whittaker et al. (2008), Amsden (1989) and Abelmann (2003, 281-282).

14 The Sŏngsu Bridge is one of the thirty-one bridges over the Han River.

15 In an interview with James B. Lee in 1996, Choi himself noted the collapses of these structures as cases of "flimflam fabrication" (one of the characteristics of the Korean city and "a distinctively modern Korean culture" inspiring his work) produced "by all the rapid changes and rupture in its recent past" (J. B. Lee 1996, 66).

16 Similar practices have been blamed for the disastrous April 2014 sinking of the South Korean ferry Sewol. Korean bureaucrats turned a blind eye to the illegal and risky redesign of the aged ferry by its owner and to its being routinely overloaded. Details of the dark connection between the owner and the network of political elites remain yet to be fully uncovered.

17 Korean workers endured low wages and poor working conditions through such "tolerance and industriousness" (Eckert et al. 1990, 402-403).

18 Throughout his term in office, Park consistently endorsed a "business-first policy," cracking down on strikes and brutally suppressing those voices advocating for workers' rights.

19 Chŏn chose death as a method of protest, which subsequently led the Korean workers' struggle to spread across the country like wildfire throughout the 1970s and 1980s.

20 Lee Bul (b. 1964) became a pioneer in the development of feminist art in South Korea through her artistic exploration during this period.

21 Lee Bul also uses fish and other everyday materials like beads and sequins in her new sculptures and installations.

22 The "adapted found object" is my term to elucidate the source of inspiration for Choi's art as distinguished from the readymade or "found object" that was adapted by the early Dada artists. Dada artists adapted manufactured and finished objects as "art objects" (readymade) to challenge the notions of creativity and originality in art in the wake of the industrial revolution. Choi, however, uses manufactured goods not as substitutes for his art as they are, but is inspired by the way that those objects as goods are actively "used" and "adapted" by and for the masses and become the indispensable fabric of their everyday life. Choi's vision in this way looks away from the Dadaists' focus on the machine as the "new hands" and restores the place and traces of human hands in readymade in the context of the objects" "usage."

23 These grassroots designs are found across Korea. Anyone who lived there during the period of accelerated growth has memories of witnessing them on random street corners and in residential alleyways and construction sites in cities and the countryside. Choi is an ardent collector of such objects as samples of vernacular design.

24 The famous Namdaemun and Gwangjang (formerly Dongdaemun) markets in Seoul, which now form a large complex that house both types of markets - open-air and enclosed stores - have originated from this traditional open-air market of old Seoul.

25 I thus call Choi's art "market pop," which was the title of earlier versions of this article. The affectionate and engaging gaze underpinning Choi's market pop is very different, as I have discussed so far in this article, from the sense of "indifference" and "ironic removal" underpinning the pop art of the American artist Andy Warhol (1928-1987) (Lucie-Smith 1994, 228; Roth 1977, 46-53). 
26 James B. Lee rightly notes that Choi's art asserts "[the objects'] specific ties to history, politics, place and class" $(1996,66)$. Comparing it to the work of American artist Jeff Koons (b. 1955), Lee notes that despite the commonality in their aspiration in adapting the popular kitsch objects, Koons substitutes the cheap original materials of the found objects with more high-end materials like porcelain and stainless steel for his final creations, as in Michael Jackson and Bubbles (1988) and Rabbit in Naples, Italy (2003). The effect of the substitution is that Koons hijacks the surfaces of the popular objects and uses them as "aesthetic" motifs, making his art a "doubly commodified kitsch," which subjects it to "the recuperative inertia of institutional and commercial processes" (Lee 1996, 66).

27 The aim of minjung art-like many democratically inspired art projects historically and across cultures - was a gradual shift in its focus from "art for people" to "art of and by people." The activities of Choi Byung-Su (a carpenter turned leading minjung artist since the early 1980s) and the Citizen's Art School (Shimin-Misul-Hakkyo, since 1983) are two notable exceptions.

28 Choi's blog also has a section dedicated to images of the popular places that inspired him and the objects he collected. It is also important to note that Choi detests conventional art exhibitions and does not typically create art for institutionalized art spaces like museums and galleries. He mostly makes art for the outdoors to blur the boundary between his "art" and the everyday. For the rare retrospective exhibition mentioned here, "Natural Color, Multiple Flower Show" (“Ch'ong-Ch'ŏn-Yŏn-Saek”) in Seoul in 2014, Choi used both indoor spaces and outdoor areas surrounding the old Seoul train station, with the indoor exhibits deliberately inviting in the popular "art" from the streets.

29 Broch noted that kitsch "falls back on the person in need of it, on the person who uses this highly considerate mirror so as to be able to recognize himself in the counterfeit images it throws back at him and to confess his own lie" (Broch 1969, 49).

30 Color, Color, Color, among Choi's early installations, narrates the gap between the ideal and the reality perceived by the members of society from the lower economic strata more explicitly through the juxtaposition of a quasi-chandelier made of myriad cheap colored light bulbs above a miniature sofa and coffee table set (Ǔngjŏpset' $\breve{u})$ in this site-specific installation. Such class dimension is signified by the very outdated and basic kitchen in which this installation is set. This kind of kitchen is typically found in houses in old underdeveloped areas of city. The sofa and table set is a symbol of the Korean middle class in the mid-1990s.

\section{References}

Abelmann, Nancy. 2003. The Melodrama of Mobility: Women, Talk, and Class in Contemporary South Korea. Honolulu: University of Hawai'i Press.

Ahn, So-Yeon. 1996a. "Choi Jeonghwa: Lives and Works in Seoul, South Korea.” In The Second Asia-Pacific Triennial of Contemporary Art. Exhibition catalogue. Queens Art Gallery, Brisbane Australia, 69-70. . 1996b. "Korean Contemporary Art in the 1990s: Between Individualism and Cultural Criticism.” Artlink 20 (2): 29-32. 
Amsden, Alice. 1989. Asia's Next Giant: South Korea and Late Industrialization. Oxford: Oxford University Press.

Beck Jee-Sook. 1999. “T’ongsokkwa idanŭi Chŭlgŏun ŭmmo” 통속과 이단의 즐거운 음모 [Choi Jeonghwa: Joyful conspiracy of vulgarity and defiance]. Wolgan Misul [Art monthly] 11 (1): 84-113.

Bok Geo-Il. 1998. “Han'guk Chishigin, Muǒsŭl Saenggakhanŭn'ga: Autsaidǒŭi Moksori” 한국 지식인, 무엇을 생각하는가: 아웃사이더의 목소리 [What do Korean intellectuals think? The voices of an outsider]. In Minŭmsa 민음사 [1998 intellectual report], edited by Minŭmsa, 11-28. Seoul: Minŭmsa.

Broch, Hermann. 1969. "Notes on the Problem of Kitsch" (1950). In Kitsch: The World of Bad Taste, by Gillo Dorfles, 49-67. New York: Universe Books.

Choi Jeonghwa. 1999. "Tijainŏ Choi Jeonghwa” 디자이너 최정화 [Designer Choi Jeonghwa]. Interiors Korea. 156:138-149.

—. 2004. "A Special Lecture by Choi Jeng-Hwa." Fine Art Department, Hongik University, Seoul, October 4.

- 2014. "Ch'ong-Ch'ŏn-Yŏn-Saek" [Natural color, multiple flower show]. Exhibition, Culture Station Seoul 284, September 4-October 19.

Cohen, Lizabeth. 2003. A Consumers' Republic: The Politics of Mass Consumption in Postwar America. New York: Vintage Books.

Curtis, Adam. 2002. The Century of the Self. Episode 1, "Happiness Machines." BBC documentary.

Dunn, Robert G. 2008. Identifying Consumption: Subjects and Objects in Consumer Society. Philadelphia, PA: Temple University Press.

Eckert, Carter J., Ki-baik Lee, Young Ick Lew, Michael Robinson, Edward W. Wagner. 1990. Korea Old and New: A History. Seoul: Ilchokak Publishers.

Haengbogi-Gadŭk'an-Ghip [Design house]. 2006. At'isŭt'ŭ Choi Jeong-hwa: Amugŏna amurŏk'ena igŏshi yesurida [Artist Choi Jeonghwa: Whatever and however, that is art]. Seoul: Haengbogi-Gadŭk'an-Ghip.

Han Hong-Gu. 2003. “Taehanminguksa: Tan'gunesŏ Kimduhankkaji” 대한민국사: 단군에서 김두한까지 [The history of Korea: From Dan-Gun to Kim Du-Han]. Seoul: Hankyoreh Sinmunsa.

Hong Sung-Tae, An Hong-Sŏp, Pak Hong-Shin, HanmiP'asŭnsŭ. 2006. Samp 'ungsago 10nyŏn' Gyohun' gwa 삼풍사고10년교훈과과제 [Ten years after the Samp'ung accident: Its lessons and tasks today]. Seoul: Bomundang.

Jacoby, Russell. 2005. Picture Imperfect: Utopian Thought for an Anti-Utopian Age. New York: Columbia University Press.

Jeong Jun-Mo. 2008. "Pulp'yŏnhan P'eisosŭ: Choi Jeonghwa” 불편한 페이소스: 최정화 [Uncomfortable pathos: Choi Jeonghwa]. Shin-Dong-A, July 30, 56-57.

Kim, Hyun-Do. 1996. "Videomatic: Beauty, Kitsch and Politics in Contemporary Korean Art." Art Asia Pacific 3 (3): 43-51.

Kim Jin-Kyung. 1996. Samshimnyŏne Sambaeknyŏnŭl San Saramŭn ŏttŏk’e Chagi Chashinil Su Issŭlkka 삼십년에 삼백년을 산 사람은 어떻게 자기 자신일 수 있을까 [How can one who lived three hundred years in thirty years be oneself?]. Seoul: Tangdae. 
Le Grand, Eva. 1999. Kundera, or, The Memory of Desire. Translated by Lin Burman. Waterloo, ON: Wilfrid Laurier University Press.

Lee, James B. 1996. “An Interview with Choi Jeonghwa.” Art Asia Pacific 3 (4): 64-67.

Lee Se-Young. 2014. "Park Chung-Hee shik kaebal 30nyŏn Shinjayujuŭi 20nyŏn pyŏngp'ye t’ŏjyŏ" 박정희식 개발 30년·신자유주의 20년 병폐 터져 [An explosion of ills after thirty years of Park Chung-Hee-style growth, and twenty years of neoliberalism]. The Hankyoreh, May 14.

Lee Young-Joon. 2004. "Mŏlt'ip'ŭl Choi Jeonghwa" 멀티플 최정화 [Multiple Choi Jeonghwa]. In Imiji Pip'yŏng: kkaeimmŏriesŏ In'gongwisŏngkkaji 이미지 비평: 깻잎머리에서 인공위성까지 [Image critique: From perilla leaf hair to satellite], by Lee Young-Joon, 34-48. Seoul: Nunbit.

Lee Young-Wook. 1996. “Toshi/ch’unggyŏk/yongmangŭi arŭmdaum” 도시/충격/욕망의 아름다움 [City/shock/beauty of desire]. Kanaat'̌ㅡ 가나아트 [Gana art]. July/August: 66-123.

Lucie-Smith, Edward. 1994. "Pop Art." In Concepts of Modern Art, edited by Nikos Stangos, 225-238. London: Thames and Hudson.

Maderthaner, Wolfgang. 2008. Unruly Masses: The Other Side of Fin-de-Siècle Vienna. New York: Berghahn Books.

McHale, John. 1969. “The Plastic Parthenon.” In Kitsch: The World of Bad Taste, by Gillo Dorfles, 98-110. New York: Universe Books.

Park Soyang. 2011. 'Oh Yoon gwa Lim Ok-Sangŭi Chakp'ume Tŭrŏnan 'Shinch'ejŏk realism' hokŭn 'Ch'ejilchŏng realism”” 오윤과 임옥상의 작품에 드러난 ‘신체적 리얼리즘' 혹은 “체질적 리얼리즘' [The return of the real: On "corporeal realism" in the works of Oh Yoon and Lim Ok-sang]. In Chŏngch'ijŏgin kŏsŭl nŏmŏsŏ: Hyŏnshilgwa Parŏn 30nyŏn 정치적인 것을 넘어서:현실과 발언 30년 [Beyond the political: Reality and utterance thirty years now], edited by Yun Beom-Mo, 91-109. Seoul: Hyŏnshilmunhwa.

Robinson, Michael Edson. 2007. Korea's Twentieth-Century Odyssey: A Short History. Honolulu: University of Hawai'i Press.

Roth, Moira. 1977. "The Aesthetics of Indifference.” Art Forum 16: 46-53.

Rupert, Mark. 1995. Producing Hegemony: The Politics of Mass Production and American Global Power. Cambridge: Cambridge University Press.

Shin Jung-Hoon. 2011. "Kŏriesŏ Paeugi: Choi Jeonghwaŭi tijain'gwa sobijuŭi toshigyŏnggwan" 거리에서 배우기: 최정화의 디자인과 소비주의 도시경 관” [Learning from the street: Choi Jeonghwa's design and consumerism-centered urban landscape]. In Shidaeŭi nun: Han'guk kŭnhyŏndaemisulgaron 시대의 눈: 한국 근현 대미술가론 [Eyes of the era: Theory of modern and contemporary artists of Korea], edited by Kwŏn Haeng-Ga 권행가 , 326-340. Seoul: Hakgojae.

Whittaker, D. Hugh, Tianbiao Zhu, Timothy J., Sturgeon, Mon Han Tsai, and Toshie Okita. 2008. Compressed Development in East Asia. MIT IPC Working Paper Series 08-005, Massachusetts Institute of Technology, October 2008. https://ipc.mit.edu/sites/default/files/documents/08-005.pdf.

Williams, Rosalind H. 1982. Dream Worlds: Mass Consumption in Late Nineteenth-Century France. Berkeley: University of California Press. 
Wong, Martin. 2003. “An Interview with Choi Jeong Hwa: Plastic Passion, Fruit Trees and Masked Buddhas." Giant Robot 30: 40-49.

Yun Nan-Jie. 2013. "Tto Tarŭn Hugijabonjuŭi, Tto Tarŭn Munhwanolli: Choi Jeonghwaŭi Plastic kihohak" 또 다른 후기자본주의, 또 다른 문화논리: 최정화의 플라스틱 기호학 [Another late capitalism, another cultural logic: The plastic semiotics of Choi Jeonghwa]. Han'guk-kŭnhyŏndae-misul-sahak한국근현 대미술사학 [Journal of Korean modern and contemporary art history] 26: 305-338. 